\title{
Corrections in Recently Described Species of Ferns and Lycophytes from the Neotropics
}

\author{
Alexander Francisco Rojas-Alvarado \\ Universidad Nacional, Heredia, Costa Rica \\ Email: alfrojasa@yahoo.com
}

How to cite this paper: Rojas-Alvarado, A.F. (2019) Corrections in Recently Described Species of Ferns and Lycophytes from the Neotropics. Open Access Library Journal, 6: e5172.

https://doi.org/10.4236/oalib.1105172

Received: January 9, 2019

Accepted: January 22, 2019

Published: January 25, 2019

Copyright $\odot 2019$ by author(s) and Open Access Library Inc.

This work is licensed under the Creative Commons Attribution International License (CC BY 4.0).

http://creativecommons.org/licenses/by/4.0/

\section{(c) (i) Open Access}

\begin{abstract}
In recent papers on ferns and allied plants, several new species names were published invalidly or illegitimately, because they had been used previously or because their type specimens were designated ambiguously. The International Code of Nomenclature for algae, fungi, and plants (Shenzhen version) was revised to remedy these situations and to apply correct names for the new taxa. Finally, new names are proposed or the correct type specimens are specified, as the case may be.
\end{abstract}

\section{Subject Areas}

Plant Science, Taxonomy

\section{Keywords}

Cyathea, Elaphoglossum, New Names, New Species, Phlegmariurus, Radiovittaria, Tryonia, Type Corrections

\section{Introduction}

The International Code of Nomenclature for algae, fungi, and plants (Melbourne code, from 2011) is the set of rules and recommendations that govern the scientific naming of all organisms traditionally treated as algae, fungi, or plants. It was actualized after XIX International Botanical Congress (IBC), which took place in Shenzhen, China in July, 2017 [1].

Several names and type species were corrected according to articles 8.1, 52.1 and 53.1 of the mentioned code [1].

\section{Materials and Methods}

Several rules of the International Code of Nomenclature for Algae Fungi and 
Plants have been taken into account to correct names and types of species recently published and that require these changes to be considered as validly published names [1]. For make the corrections the following publications have been reviewed: Rojas [2] [3], Rojas and Calderón [4] and Rojas [5] [6]. Also the new names were corroborated with International Plant Name Index [7].

http://www.ipni.org/ipni/plantnamesearchpage.do

\section{Results}

In this paper Elaphoglossum hernandeziae is published as new species for replace the invalid name Elaphoglossum karinae [2] because it was published including type material of previously valid name species. Also Elaphoglossum $\times$ morphohybridum and Phlegmariurus tico are new names for Elaphoglossum $\times$ intermedium [3] and Phlegmariurus nanus [4] respectively, because that names was published previously as valid names. Finally, the correct type specimens for Radiovittaria salvo-tierrana [5] and Tryonia macrophylla [6] are mentioned, and in the case of Cyathea $\times$ hybrida [3] the incorrect use of the name Cyathea $\times$ robusta is explained.

\subsection{New Species}

\section{Elaphoglossum hernandeziae A. Rojas, sp. nov.}

1) Type. HONDURAS. Lempira: Gracias, Celaque Mountains National Park,

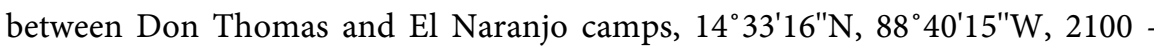
2575 m, 27 Jun 2012, A. Rojas et al. 9982 (holotype: CR; Isotypes: EAP, TEFH).

2) Diagnoses. Elaphoglossum hernandeziae differs from E. dissitifrons Mickel by its shorter rhizome, with longer and relatively narrower, lanceolate to linear-lanceolate scales and blackish costal scales.

3) Description. Epiphytic; rhizome 2 - $3 \mathrm{~mm}$ in diameter, creeping, distance between fronds $2-5(-10) \mathrm{mm}$; rhizome scales $5-10 \times 1-2 \mathrm{~mm}$, lanceolate, gold or with brown patches, peltate, flaccid, patent, marginally entire to short-ciliate; fronds 18 - $46 \mathrm{~cm}$ long; phyllopodia 7 - $15 \mathrm{~mm}$ long; stipe 5 - 23.5 $\mathrm{cm}$ long, 1/2 - 1/4 of the frond length, stramineous, scaly at least at the base, the scales 2 - $5 \times$ ca. $1 \mathrm{~mm}$, the basal ones marginally entire and the others longciliate; blade 13 - $24 \times(2.1-) 2.5-4.3 \mathrm{~cm}$, elliptic, oblong-elliptic or oblanceolate, coriaceous, basally cuneate, apically obtuse to rounded; costa stramineous, scaly or glabrous, the scales $1-2 \times$ ca. $0.5 \mathrm{~mm}$, lanceolate, gold-brown to brown, sparse, marginally with lateral processes; laminar tissue glabrous on both surfaces; veins few evident; fertile fronds 13 - $37 \mathrm{~cm}$ long; stipe (3-) 10 - $20.5 \mathrm{~cm}$ long; blade $9.5-17 \times 1.6-2.7 \mathrm{~cm}$, elliptic to oblong, basally cuneate, apically acute to obtuse; intersporangial scales absent.

4) Etymology. This species is dedicated to Ruth Karina Hernández Cibrián, pteridologist in Honduras, who collaborated with the Celaque expedition in 2012.

5) Distribution. Known from Mexico, Guatemala, Honduras, and El Salvador, at (1400-) 1900 - 3050 m elevation. 
6) Additional specimens examined. MEXICO. Chiapas: Mpio. Chamula, NE slope of Zontehuitz near the summit, $9300 \mathrm{ft}$ [=2835 m], D. Breedlove 7812 (F); Mpio. Tenejapa, NE side of the hill called Matsab, Paraje of Matsab, $9200 \mathrm{ft}$ [=2804 m], D. Breedlove 15292 (F); Mpio. Tenejapa, in the Paraje Matsab, 8900 $\mathrm{ft}$ [=2713 m], A. Shilom 694 (F). Oaxaca: Teotitlán, 2500 m, C. Conzatti et al. 2137 (MEXU); along road from Teotitlán del Camino to Hautla de Jiménez, 17.8 - 18.3 miles E of Teotitlán, 2300 - 2370 m, T. Croat 48214 (MO, NY, UC); Dist. Ixtlán, Sierra de Juárez, Km 90 of rute 175 Tuxtepec-Oaxaca, SW of La Esperanza, 2035 m, D. Lorence et al. 3618 (MEXU, MO); Dto. Teotitlán, 26 - 29 km NE of Teotitlán del Camino, vicinity of pass of Puerto Soledad, $7000-7400 \mathrm{ft}$ [ $=2134$ - 2256 m], J. Mickel and R. Hellwig 4152 (NY, UC); Dist. Mixes, SE shoulder of Cerro Zempoaltepetl, $8200 \mathrm{ft}$ [=2500 m], J. Mickel and S. Leonard 4910 (NY, UC); Dist. Ixtlán, Cerro de Malacate, $\mathrm{N}$ of Capulalpan, ca. $8 \mathrm{~km}$ E of Ixtlán from $7600-10,000 \mathrm{ft}$ [=2316 $-3048 \mathrm{~m}$ ] on NE side of Cerro, $8850 \mathrm{ft}$ [=2697 m], J. Mickel and S. Leonard 5246 (NY, UC), J. Mickel and S. Leonard 5299 (NY, UC); Dist. Ixtlán, $56 \mathrm{~km} \mathrm{~N}$ of Ixtlán on Rte. 175, 7100 ft [=2164 m], J. Mickel 5593 (NY, UC); Teotitlán de Flores Magon, Raya San Gerónimo, 4 km SE of Plan de Guadalupe, path to Mazatlán de Flores, $18^{\circ} 10^{\prime} \mathrm{N}, 97^{\circ} 01^{\prime} \mathrm{W}, 2800 \mathrm{~m}, \mathrm{P}$. Tenorio and F. Tenorio 18553 (MEXU).

GUATEMALA. Guatemala: Volcán Pacaya, above Las Calderas, 1800 - 2400 m, P. Standley 58487 (F, US). San Marcos: Volcán Tacaná, along Quebrada Canjula, between Sibinal and Canjulá, 2200 - 2500 m, J. Steyermark s.n. (US). Zacapa: Sierra de Las Minas, between Loma El Picacho and Cerro de Monos, 2000 - 2600 m, J. Steyermark 42813 (GH).

HONDURAS. Comayagua: San Juanillo, section of the Cordillera de Montecillos Biological Reserve, 9 Dec 1991, T. Hawkins et al. 121 (EAP); Montana de San Juanillo, Cordillera de Montecillos Biological Reserve, path El Danto to Jesús de Otoro, $14^{\circ} 30^{\prime} \mathrm{N}, 87^{\circ} 53^{\prime} \mathrm{W}, 1900$ m, 1 Mar 1991, P. House and S. Aguilar 846 (EAP, MO, TEFH). El Paraíso: Yuscarán, Cerro Monserrat, 2000 m, A. Díaz 180 (CR, UC); ibidem, Zelaya 129 (CR, MO, UC). La Paz: Maguore, 4 $\mathrm{km}$ NW of Guajiquiro, $14^{\circ} 09^{\prime} \mathrm{N}, 87^{\circ} 51^{\prime} \mathrm{W}, 2100 \mathrm{~m}, 24$ May 1993, R. Liesner 26528 (EAP, MO, TEFH, UC). Lempira: Montaña de Celaque, SE portion of the massif, main peak just $\mathrm{S}$ of the Río Aragual, on plateau, $14^{\circ} 32^{\prime} 30^{\prime \prime} \mathrm{N}, 88^{\circ} 41^{\prime} 00^{\prime \prime} \mathrm{W}$, 2670 m, 2670 m, 29 May 1991, G. Davidse 34878 (EAP, MO); Celaque National Park, along Río Arcagual, between visitor's center and dam (water intake for the town of Gracias), $7.5 \mathrm{~km}$ WSW of Gracias, $14^{\circ} 34^{\prime} \mathrm{N}, 88^{\circ} 39^{\prime} \mathrm{W}, 1400 \mathrm{~m}, 11 \mathrm{Nov}$ 1991, R. Moran 5515 (MO, UC); Celaque National Park, along Río Arcagual, upstream from base camp 2, $10.5 \mathrm{~km}$ WSW of the town of Gracias, $14^{\circ} 34^{\prime} 05^{\prime \prime} \mathrm{N}$, 8841'05"W, 2500 m, 16 Nov 1991, R. Moran 5592 (EAP, MO, TEFH). Santa Bárbara: Montaña Santa Bárbara, 2350 m, 7 Apr 1951, R. Armour and A. Chable 6123 (EAP); $7 \mathrm{~km} \mathrm{~N}$ of El Monchito, on the E slopes of Mt. Santa Bárbara, $14^{\circ} 55^{\prime} \mathrm{N}, 88^{\circ} 7^{\prime} \mathrm{W}, 2200-2500$ m, 23 Nov 1991, R. Moran 5704 (EAP, MO, TEFH, $\mathrm{UC})$. 
EL SALVADOR. Bosque Montecristo, R. Seiler 657 (NY). Chalatenango: E side near summit of Eses Miles, $14^{\circ} 21^{\prime} \mathrm{N}, 89^{\circ} 09^{\prime} \mathrm{W}, 2500 \mathrm{~m}$, J. Tucker 1071 (NY, UC, US). Santa Ana: Montecristo, $14^{\circ} 25^{\prime} \mathrm{N}, 89^{\circ} 22^{\prime} \mathrm{W}, 2100$ - 2250 m, 27 Jan 1998, G. Davidse et al. 37290 (BM, MO); Montecristo, 2300 m, 23 May 1963, A. Molina and A. Molina 12659 (EAP).

7) Observations. Elaphoglossum hernandeziae differs from E. dissitifrons by its shorter [fronds distant $(0.2-) 0.5-1.0 \mathrm{~cm}$, vs. $0.8-1.7 \mathrm{~cm}$ ] rhizome, longer [(4-) 7 - $12 \mathrm{~mm}$, vs. 5 - $7 \mathrm{~mm}$ ] and relatively narrower [1 - $2(-3) \mathrm{mm}$, vs. 1.5 $3.0 \mathrm{~mm}$ )] rhizome scales, which are lanceolate to linear-lanceolate (vs. ovate to ovate-lanceolate), and blackish (vs. yellowish-brown) costal scales.

This taxon was previously published as Elaphoglossum karinae A. Rojas [2], but the type specimens of two other species (E. clewellianum Mickel and E. martinezianum A. Rojas) were mistakenly cited among the paratypes. Thus the name E. karinae is illegitimate, according to Article 52.1 of the International Code of Nomenclature [1], for which reason the taxon is here provided with another name.

\subsection{New Names}

\subsubsection{Elaphoglossum $\times$ Morpho Hybridum A. Rojas, nom. nov.}

1) Replaced synonym. Elaphoglossum $\times$ intermedium A. Rojas in Rojas [3], nom. illeg., non E. intermedium Brack. (U. S. Expl. Exped. Filic. 16: 69. 1854).

2) Type. COSTA RICA. Puntarenas: Puntarenas, Isla del Coco, Parque Nacional Isla del Coco, Meseta Occidental, in the springs of Quebrada Albatros, $5^{\circ} 31^{\prime} 15^{\prime \prime} \mathrm{N}, 87^{\circ} 04^{\prime} 40^{\prime \prime} \mathrm{W}, 350-400$ m, 1 Jan 2011, A. Rojas and C. Herrera 9281 (holotype: CR; isotype: $\mathrm{MO}$ ).

3) Etymology. The specific epithet refers to the intermediate morphology between the putative progenitors.

4) Observations. Elaphoglossum $\times$ morphohybridum differs from E. alvaradoanum because it has longer (ca. $1 / 4$ of the frond length, vs. (1/5-) 1/10-1/20) stipes and oblanceolate (vs. narrowly oblanceolate) and broader $(6-9 \mathrm{~cm}$, vs. $(2.8-) 3.5-4.9 \mathrm{~cm}$ ) leaf-blades with a cuneate (vs. attenuate) base and obtuse (vs. acuminate) apex and partially reticulate (vs. free) veins. It is also similar to E. crinitum, from which the putative hybrid differs in its proportionally shorter (ca. 1/4 of the frond length, vs. ca. 1/2) stipes and oblanceolate (vs. broadly elliptic) and narrower (6 - $9 \mathrm{~cm}$ vs. 8-) $10-20 \mathrm{~cm}$ ) leaf-blades with a cuneate (vs. rounded) base and obtuse (vs. rounded) apex and partially reticulate (vs. completely reticulate) veins. Additionally, the rhizome thickness, frond size, and blade-scale size of the new taxon are intermediate between those of its putative progenitors.

This taxon was previously published as Elaphoglossum $\times$ intermedium A. Rojas in Rojas [3], but that name had been previously published and is thus illegitimate, according to Article 53.1 of the International Code of Nomenclature [1]; therefore, a new name is here assigned. 


\subsubsection{Phlegmariurus tico A. Rojas, nom. nov.}

1) Replaced synonym. Phlegmariurus nanus A. Rojas and R. Calderón in Rojas and Calderón [4], nom. illeg., non P. nanus C.Y. Ma (Bull. Bot. Res., Harbin 10(3): 58 - 60, pl. 3. 1990).

2) Type. COSTA RICA. Heredia: Heredia, Varablanca, near the trail to Sarapiquí, $10^{\circ} 09^{\prime} 37^{\prime \prime} \mathrm{N}, 84^{\circ} 09^{\prime} 21^{\prime \prime} \mathrm{W}, 1925 \mathrm{~m}, 29$ Sep 2013, A. Rojas and M. Obando 10517 (holotype: CR; Isotypes: MO, K, USJ).

3) Etymology. The specific epithet refers to the known distribution only in Costa Rica.

4) Additional specimens examined. COSTA RICA. Alajuela: trail between Ciudad Quesada and Zarcero, 5 abr 1958, M. Álvarez 40 (CR, 38966); Cinco Esquinas de Carrizal, 800 varas antes del Pueblo, 11 abr 1958, M. Álvarez 56 (CR, 38969); trail to Volcán Poás, 1950 m, 22 jun 1958, M. Álvarez 63 (CR, 38971). Cartago: between Volcán Irazú and Hotel Robert, 18 jun 1958, R. Rodríguez and A. Jiménez 158 (CR, 37060). Heredia: trail to Volcán Barva, 1990 m, 23 sep 1958, M. Álvarez 113 (CR, 38987); ibídem, 1900 m, 23 sep 1958, M. Álvarez 117 (CR, 38990); Santa Bárbara, Santo Domingo, rising from Cinco Esquinas, West side of Volcán Barva, near of dirt road, $10^{\circ} 07^{\prime} 20^{\prime \prime} \mathrm{N}, 84^{\circ} 06^{\prime} 45^{\prime \prime} \mathrm{W}$, ca. 2100 m, 3 dic 2014, A. Rojas and I. Chinchilla 10878 (CR, USJ); San Rafael, Los Ángeles, trail to Cerro Chompipe, $10^{\circ} 04^{\prime} 45^{\prime \prime} \mathrm{N}, 84^{\circ} 04^{\prime} 37^{\prime \prime} \mathrm{W}, 2000 \mathrm{~m}, 28$ set 2013, A. Rojas et al. 10516 (CR). San José: Coronado, Cascajal, farm of Mario Echandi, $10^{\circ} 00^{\prime} 47^{\prime \prime} \mathrm{N}, 83^{\circ} 57^{\prime} 09^{\prime \prime} \mathrm{W}, 1730 \mathrm{~m}, 26$ oct 2014, M. Pérez 103 (USJ); trail to Cascajal de Coronado, 28 jul 1957, A. Jiménez 26 (CR); San Ramón de Tres Ríos, 20 feb 1959, R. Rodríguez 597 (CR, 36708).

5) Observations. Phlegmariurus tico differs from P. reflexus (Lam.) B. Øllg. by its solitary (vs. clustered), shorter [5-11 cm vs. $10-30(-40) \mathrm{cm}]$, simple to once-dichotomous (vs. 2 - 5- dichotomous) stems amd sparsely ciliate (vs. dentate) leaves, with the cilia $0.1-0.3 \mathrm{~mm}$ long (vs. $0.05-0.15 \mathrm{~mm}$ ).

This taxon was previously published as Phlegmariurus nanus A. Rojas and $\mathrm{R}$. Calderón in Rojas and Calderón, but that name had been previously published and is thus name illegitimate, according to Article 53.1 of the International Code of Nomenclature [1]; therefore, a new name is here assigned.

\subsection{Type and Name Corrections}

\subsubsection{Radiovittaria salvo-Tierrana}

A. Rojas, Acta Bot. Malac. 42: 18 - 19, f. 2A, B. 2017.

1) Observations. This name was published invalidly, according to Article 40.1 of the International Code of Nomenclature [1], because Rojas [5] mentioned two specimens, E. Killip and J. Cuatrecasas 38895 (US) and A. Gentry et al. 68374 (COL), were designated as "Holotipo" or "Holotype" (respectively). Here the correct type is designated, as defined by Article 8.1 of the same code.

2) Type. COLOMBIA. Valle: Agua Clara, along hwy. of Buenaventura to Cali, 100 m, 6 July 1944, E. Killip and J. Cuatrecasas 38895 (Holotype: US; Isotypes: COL, VALLE). 


\subsubsection{Tryonia macrophylla}

A. Rojas, Acta Bot. Malac. 42: 115 - 116, f. 4A, B. 2017.

1) Observations. This name was published invalidly, according to Article 40.1 of the International Code of Nomenclature [1]; because two specimens, $B$. Ramírez and D. Macías 14383 (COL) and A. Arbeláez et al. 470 (HUA), were designated as "Holotipo" [6]. Here the correct type is designated, as defined by Article 8.1 of the same code.

2) Type. COLOMBiA. Cauca: Municipio de Almaguer, Vereda El Jordán, between quebrada Agua El Oro and La Mina, 2450 - 2600 m, 28 July 2001, B. Ramírez and D. Macías 14383 (Holotype: COL; Isotype: CAUP).

\subsubsection{Cyathea $\times$ Hybrida}

A. Rojas, Acta Bot. Malac. 42: 95 - 96, f. 2A-D, 6A1C, D. 2017.

Observations. This name was the intended name for putative hybrid between Cyathea alfonsiana L.D. Gómez and C. notabilis Domin (Rojas [3] published online, Dec. 2017). Unfortunately, the new taxon was accidentally referred to as "Cyathea $\times$ robusta" (the previously considered name) throughout the paper. However, the correct ( $C . \times$ hybrida) name appears in the heading of the main entry (and the "Etymology" paragraph states that "the name of the new nothospecies refers to its hybrid condition"). In any event, the epithet robusta cannot have been used, as it is preoccupied in Cyathea by C. robusta (C. Moore ex Maiden) Holttum (1964; Blumea 12: 265).

\section{Acknowledgements}

This work was made possible thanks to Universidad Nacional (UNA) for finance some trips to visit different herbaria, to Sistema Nacional de Áreas de Conservación (SINAC) and Mancomunidad de Municipios del Parque Nacional Montañas de Celaque (MAPANCE PROCELAQUE), del Instituto Nacional de Conservación y Desarrollo Forestal, Áreas Protegidas y Vida Silvestre (ICF) for the authorization to make collections in the Costa Rican and Honduras protected areas. Thanks also to Museo Nacional de Costa Rica, Herbario Nacional de Costa Rica (CR) and Universidad Nacional de Colombia, Instituto de Ciencias Naturales, Herbario Nacional Colombiano (COL), Escuela Agrícola Panamericana herbarium (EAP), Universidad de Antioquia Herbarium (HUA), Universidad Nacional Autónoma de México, Instituto de Biología (MEXU), Missouri Botanical Garden (MO), New York Botanical Garden (NY), Universidad Nacional Autónoma de Honduras Herbarium (TEFH), University of California Herbarium (UC), Smithsonian Institution, US National Herbarium (US), Universidad Nacional de Colombia, Sede Palmira, Valle del Cauca (VALLE) and their curators for good attention and facilitates. Thanks to Michael Grayum for the excellent suggestions about the botanical code of nomenclature. To the anonymous reviewers for their help; and to all who, in one way or another, made this work possible. 


\section{Conflicts of Interest}

The author declares no conflicts of interest regarding the publication of this paper.

\section{References}

[1] Turland, N.J., Wiersema, J.H., Barrie, F.R., Greuter, W., Hawksworth, D.L., Herendeen, P.S., Knapp, S., Kusber, W.-H., Li, D.-Z., Marhold, K., May, T.W., McNeill, J., Monro, A.M., Prado, J., Price, M.J. and Smith, G.F., Eds. (2018) International Code of Nomenclature for Algae, Fungi, and Plants (Shenzhen Code). Adopted by the Nineteenth International Botanical Congress Shenzhen, China, July 2017. Regnum Vegetabile 159. Koeltz Botanical Books, Glashütten.

https://doi.org/10.12705/Code.2018

[2] Rojas, A.F. (2017) Three New Species of Ferns (Pteridophyta) from Mesoamerica. American Journal of Plant Sciences, 8, 1329-1338.

https://doi.org/10.4236/ajps.2017.86089

[3] Rojas, A.F. (2017) A New Species and Three Hybrids in the Ferns from Cocos Island, Puntarenas, Costa Rica. Acta Botánica Malacitana, 42, 91-99.

https://doi.org/10.24310/Actabotanicaabmabm.v42i0.2383

[4] Rojas, A.F. and Calderón, R.R. (2017) Dos especies nuevas de Phlegmariurus Holub (Lycopodiaceae) para Costa Rica. Acta Botánica Malacitana, 42, 67-70. https://doi.org/10.24310/Actabotanicaabmabm.v42i2.2972

[5] Rojas, A.F. (2017) Novedades en Radiovittaria (Benedict) E.H. Crane (Pteridaceae) para el Neotrópico. Acta Botánica Malacitana, 42, 15-21.

https://doi.org/10.24310/Actabotanicaabmabm.v42i2.3014

[6] Rojas, A.F. (2017) Novedades en Jamesonia y Tryonia (Pteridaceae) para el Neotrópico. Acta Botánica Malacitana, 42, 111-118.

https://doi.org/10.24310/Actabotanicaabmabm.v42i0.3027

[7] The International Plant Names Index (2012)

http://www.ipni.org/ipni/plantnamesearchpage.do 